\title{
A Puzzle of Poetic Expression
}

John Gibson explores literary models of selfhood

A self, it is sometimes thought, is not so much a kind of thing as a kind of achievement. We can fail to have a self, in some relevant sense, much as we can fail to have a sense of humour or a way with words. Failure here is surely a matter of degree; and putting the matter this way indicates that the kind of self we are talking about is a fairly robust thing. It is not the "minimal" self that seems implicated in all conscious experience but the aspect of the person that articulates and gives domicile to identity, that it is, to a sense of self: a conception of how we hang together as thinking, feeling, and valuing beings.

There is much disagreement about how we manage to build selves so conceived, but for roughly the past forty years a number of philosophers have looked to literature for inspiration. If the self is a kind of achievement, some of the most exciting work in the debate has argued that it is in effect a narrative achievement: we create a sense of self through acts of story-telling. The idea, perhaps reasonable, is that the writer's talent for creating exemplary narratives - exemplary in their ability to render persons and their lives coherent and meaningful - has something to show us about how we can do the same, though presumably with less artistry and aesthetic flair. Narrative, the idea goes, is what allows us to make available to ourselves and others a sense of being a kind of person burdened with a kind of life, and to be able to describe both as endowed with varieties of purposiveness and significance (or as failing to be endowed with these things, which seems the preferred narrative of the nihilist and Galen Strawson).

I find much to admire in the narrative approach, but I want to suggest that we look in a different direction for a moment, away from the novelist and to the poet. On the face of it, lyric poetry is the most manifestly self-obsessed art form we possess, an artistic form in which the I is given tremendous freedom to explore itself. It is surprising and a tad irresponsible that philosophers who think that literature has much to teach us about selves have utterly ignored the poet. What I think the poet brings to our attention is that a sense of self can be, and often is, generated through a powerful kind of expressive act and not, or not just, through a feat of story-telling. Or so I wish to suggest.

The matter, however, gets complicated very quickly. An account of what poetic expression can tell us about selves obliges us to take seriously the idea that poetry is, in some sense and on certain occasions, self-expressive; so much is implied by the way I have set up the problem. Yet understanding what this means in properly philosophical terms is no easy affair. We must supply a self for a poem's expressive handling, and finding one is where the trouble starts. There are three places we might 
look for the self that is the subject of poetic expression, and it is worth considering each. I save the best for last, and on the road there we will gain some clarity on what we should and should not expect the poet to have to show us about persons.

\section{Authorial Model.}

The most intuitive route to understanding poetic self-expression is also the one philosophers are certain is doomed. It is the idea that poems are literally and straightforwardly self-expressive in the sense that they "manifest" the psychological states of their authors. Call this the authorial model.

In standard or paradigmatic cases, self-expression aims at transparency. This claim is found just about anywhere one finds contemporary work on self-expression literally socalled. The flash of disapproval in the face of the parent whose child won't eat his peas, the "I am really bored" whispered to a friend at lifeless party, or the terror in the eyes of one on whom you've just played a very nasty trick, show something about the self, revealing directly, in perfect cases, one's state of mind.

The idea that poets do such a thing when writing expressive poems is ludicrous. Even an apparently transparent, confessional line such as Robert Creeley's "I know I only constitute a meager mind and voice" refuses to be taken as mere spiritual reportage, not because it isn't true of Creeley - who knows? - but because the line is part of a constellation of words that culminate in a poem, and the poem, though clearly expressive and clearly about a self, is an artistic and aesthetic object, and so hardly apt for reflecting a soul as it is. A soul can be turned into art, and perhaps Creeley does just that in "Goodbye". But if a soul isn't also an artwork and an aesthetic object in its natural state, then we are speaking of self-expression now in an atypical way, and that is the point, since it calls on us to understand what it means now, in the poetic instance, since it does not mean what it does in standard cases.

\section{Philosophers have utterly ignored the poet}

A poet clearly has a crucial role to play in determining the expressive properties her poems bear. It would be madness to deny this. But the argument against the authorial model is that these properties do not become self-expressive because they simply function to reveal what the poet happens to feel inside. The creation of art, as R. H. Collingwood insisted, is a process wherein an artist explores and attempts understand her emotions. But then the defined emotion is, in a profound sense, in the completed work of art, brought to life there. It was not around for the ride and simply made ever more visible during the journey. If we encounter someone who regards a poem as a pure and faithful recording of the poet's inward emotions, all we would need to do to disabuse him of his innocence would be to point out that when someone looks within, what she finds is never organised into stanzas, is not late modernist, and cannot be intelligibly seen as an instance of the Black Mountain Movement. To think otherwise has the risible consequence of making a poet appear to traffic in a spiritual version of readymade art. A poet's self is just repurposed for the world of poetry, much as Duchamp repurposed a urinal for the Society of Independent Artists. 


\section{Readerly Model.}

Kendall Walton has recently shown something remarkable. We can be entirely literal when speaking of poetic self-expression, and we can do this by locating the relevant self not in the body of the poet but in the body of the reader. Call this the readerly model: the consumer of poetry supplies the self that the author does not and, apparently, cannot. It must be acknowledged that Walton's sights are not quite on the issue I am exploring here. He wants to understand one way we come to experience a poem as self-expressive. We can grant that he has found this, and my concern is to see whether it can be enlisted in the service of providing a general model of the self that poems make their object of expressive interest.

Walton begins with the claim that, "it is not unlikely that poets sometimes have, as at least part of their purpose in composing a poem, the objective of making their words available for use by their readers." A poem, the idea goes, expands the range of feeling and perspectives with which we can identify and so enlist in our own self-expressive projects. As Walton puts it in "Thoughtwriting - in Poetry and Music", a poet is like a speech-writer, and speechwriters "don't use the words they inscribe (not insofar as they are speechwriters); they mention them. They produce a text for use by someone else." In virtue of self-identifying with a lyric, the reader, if you will, puts her self on loan to poem and thereby makes it self-expressive. A poem becomes genuinely and literally self-expressive when a reader says 'you speak for me' to the lyric and means it.

This surely happens, and Walton's is right to see readerly identification as part of the story of why we often care about a poem's expressive activity. But there are certain limita- tions to this theory. In part of us it conjures up an image of that awkward moment at weddings everywhere when the groom produces a poem, usually poorly chosen, and recites it to the bride, at which we smile politely but feel mild embarrassment. And one might also wonder how many poems will oblige when we use them to declare our own thoughts and feelings. Surely with most poems the best we can do is borrow a few lines, cherry-picked to match our self-expressive goals. Given the facts of my personhood such as they are, am I genuinely capable of such an act of self-identification with a poem such as Sylvia Plath's "Metaphors" or Paul Celan's "Death Fugue", the first evidently about one's pregnant body and the second, though supremely enigmatic, the expressive act of one who has to speak on behalf of an experience I surely cannot: the Shoah. Only self-deception and self-flattery would allow me to claim the I's of those lyrics and think I mean it, that the identification we are all surely capable should be seen as a form of self-identification. Now a defender of the readerly model will respond that I should just choose better poems, namely ones with which I actually can expressively self-identify. But my point suffices to reveal the worry one should have about linking poetic self-expression so directly to the reader, for it renders the set of poems I can experience as self-expressive likely absurdly small.

Note also that a tremendous array of emotions we experience in the context of poetry are other-directed emotions, and the vast meness of a readerly model will not be able to accommodate this. Other-directed emotions are the kinds of emotions we have toward persons when their plights move us. Empathy and sympathy are presumably at times appropri- 


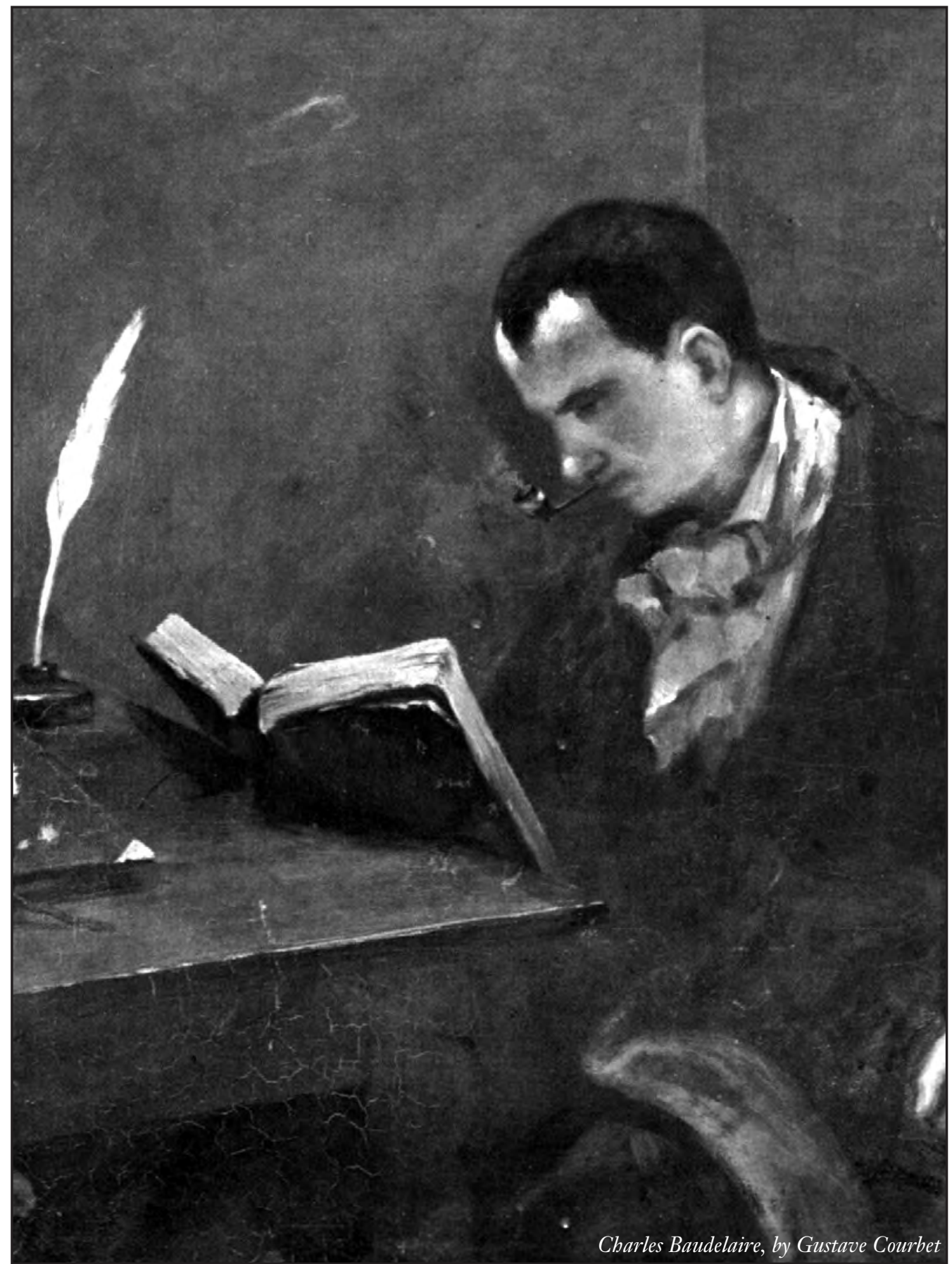


ate affective responses to a poem, as are care, concern, compassion, pity, and, at times, even contempt (such as when I read Charles Bukowski). All these emotions require clear self-other differentiation. In the case of poetry, the object of these emotions would presumably be the self given expression in the poem. And while we do not yet know what that self is, is simply cannot be my self. Consider. I feel a sense of awe at the manner in which in Louise Glück's "The Wild Iris” makes a cycle of plant life an object of intense affective concern. In the poem, an iris returns from the "oblivion" of winter to find, presumably on a fine Spring day, that

from the center of my life came a great fountain, deep blue shadows on azure seawater.

On the readerly model, it would seem that if I feel awe in this poem's accomplishment of self-expression, then it must be myself that I find awesome, the narcissism of which is imponderable. Too bad for the blossoming iris, who does so much to make herself the object of regard.

\section{Lyrical model.}

One will have noticed that neither the authorial nor readerly model has much to say about what poetry might show us about what selves are and how we get them. They are both realist and literalist models of self-expression: poetry expresses the feelings of an actual self in a way that is continuous with our workaday attempts to enlist language to express our psychological states. This might tell us how a self feels, but it appears to reveal precisely nothing about what a self is. I suggest, then, abandoning literalism here. The concept of poetic self-expression does not call on us to find an actual self. And we also accept that in the context of poetry, self-expression means something quite other than it does in standard or ordinary contexts. Call this a lyrical model, the basic claim of which is that the self implicated in a poem is an effect of poetic language, and it exists solely there, created by and confined to a poem's lyrical activity.

\section{In the absence of nearly all biographic detail, we see the bare form of person begin to take shape}

The idea is this. By engaging with the content of a poem imaginatively, we come to hear it as voiced, that is, as presented by a speaker whose existence we merely have to entertain. In virtue of this, and contrary to Walton, we hear the words that animate the voice as used and not merely mentioned. And this becomes interesting not because we can say that in poetry we find an imagined speaker expressing her fictional mental states. This is not interesting at all. We mean something very different than the literalist does when we speak of a certain class of self-expressive acts, the poetic included. This is the class that has as its goal not expressing how one feel inside but revealing a much more fundamental feature of personhood.

An example would help here. Consider George Oppen’s “From Disaster” (1962) 
Ultimately the air

Is bare sunlight where must be found

The lyric valuable. From disaster

Shipwreck, whole families crawled

To the tenements, and there

Survived by what morality

Of hope

Which for the sons

Ends its metaphysic

In small lawns of home.

Oppen began his poetic career in the 1930s as an Objectivist, a movement of modernism's second-generation that had absolutely nothing to do with Ayn Rand. Objectivists insisted on the poem as an object rather than a confession, and on the poet as an engaged perceiver rather than a soul-searcher, and they intended this as a rebuke to writers who make the exploration of subjectivity and not the world the place of poet action. We see this very clearly in this late poem. The poem is fascinating, for my purposes, because it uses so few resources to generate such a rich and nuanced sense of a self. Over four stanzas that yield a mere ten lines, we are given an image of a person who is of a sort to: reject aestheticism (the idea of art for art's sake), endorse Marxism (Oppen in fact did), see immigrants as arriving to horror twice over - first urban poverty and then, more terribly, the "small lawns" of suburban life and hence of middle-class complicity - and to take little hope that art is winning the battle against the cultural and political forces it strives to transform.

I confess a reliance here on critics better than myself, and some critics will of course disagree with one or another claim I have made about the lyric and just what it is giving voice to. But this isn't a problem for my general point. For the philosopher concerned with selves, what is interesting about these disagreements is that they each can be read as arguments about the standing values, commitments, disappointments, and hopes implied by a voice inclined to utter lines such as these. In a word, they are claims about how the voice in the poem, given the manner in which expresses itself, appears to hang together as a person: as a thinking, feeling, and valuing being. They are not quite descriptions of discrete (occurrent) mental states so much as statements of implied character.

What is philosophically remarkable about poems such as this is that in them we see virtually none of those features much philosophy of self tells us is necessary for constructing a sense of self. Oppen's accomplishment here is to evaluate from the poem so much of what we take to be required to express a self-concept. It is an artistic exercise in reduction. We are given a handful of highly figurative lines that outline, if you will, the speaker's field of perceptual and affective attention. No facts of the speaker's history are revealed, and indeed the poem never once uses a first-person pronoun. Nothing "narrativists" claim is essential to crafting a sense of self is happening here, clearly. Yet in the absence of nearly all biographic detail, we see the bare form of person begin to take shape. The expressive content of the lines is perceptual and reflective, and these lines coalesce into the outline of perspective. We have the construction of an image of one who perceives, thinks, and feels in this way, and the poem shows us that this is one manner in which we outline what a person is. It is a person as a distinct perspective: as the site of a 
particular purchase on the world. That is one way of understanding what a self essentially is.

\section{A soul can be turned into art}

Whatever notion of a self is implicated in this, I suspect the interest we can take in it is nearly always exhausted by the interest we can take in the presence of voice in the poem. If we find it odd to wonder how we experience a self in a poem, the queerness of the idea dissipates once we recast it in terms of the experience of a voice. And at this point the search for a real self to supply a soul for self-expression seems an uninteresting affair. Indeed, anyone who reads enough poetry will know, at times the voice of a lyric can be disembodied, or the voice of a culture, a nightmare, Kant's transcendental subject, or whatever. We thus should very much be disinclined to be literalists about the kind self implicated in poetry. It is a virtue of the lyrical model that it can accommodate this. And note that even when disembodied or harnessed to abstract objects, a voice can still have much to show us about how its bearer hangs together. We just would do well not to imagine it hanging together in an actual human body.

The notion of voice, as I am using it here, is intended to highlight a very precise accomplishment: when our expressive acts are exemplary as acts of self-disclosure, what we say conveys not merely this feeling or that thought, this want or that experience, but, along with all this, a sense of how we are constituted as selves. Conceived lyrically, then, self-expression is not a matter of making public discrete thoughts and feelings we feel compelled to share. It is not that sense of expression at all.
It is self-expression as a matter of speaking in such a way that general features of who we are brought to view through the particular things that we say. Our style of expression, and our manner of giving voice to the concerns that animate us, count for everything here.

We do need to acknowledge that in our small achievements of voice, we do not thereby achieve poetry; the poet's voice must bear significant aesthetic fruit, and, sadly, we rarely live up to this. This problem also plagues the narrative view of the self, for if life is to be modelled on literary narratives, we run into the obvious problem that the narratives of most human lives, unlike those of most novels, are not interesting, are usually poorly told, begin clumsily and end terribly, and lack, well, the literariness of literature. The same, presumably, with our voices and their attempts at self-expression. But the bullet to be bitten here is clear. The poet, like the novelist, is just an exemplum in our theories of selfhood, offering ideals to which we only very imperfectly attain. What is important is that this literary model of the self, interpreted either novelistically or poetically, can cast light on our own attempts to use words to shape a sense of self. In the novel or the poem, we see in a purer form the structure of certain acts of self-articulation. Life isn't literature, but literature can, certainly on occasion, give us the exemplary instance. What I have done here is argue that the literary model of selfhood would do very well to consider also the poet when explaining how we make sense of, as the late Peter Goldie put it, the mess inside.

John Gibson is associate professor of philosophy at the University of Lonisville. He is the author of Fiction and The Weave of Life (Oxford, 2007) and editor of The Philosophy of Poetry (Oxford, 2015). 